ELORE (ISSN 1456-3010), vol. $12-1 / 2005$.

Julkaisija: Suomen Kansantietouden Tutkijain Seura ry. Taitto: Jukka Talve.

[http://cc.joensuu.fi/ /oristi/1_05/mah_b_1_05.pdf]

\title{
KATSAUKSIA:
}

\section{Mitä TUliKaAN LUVATTUA?}

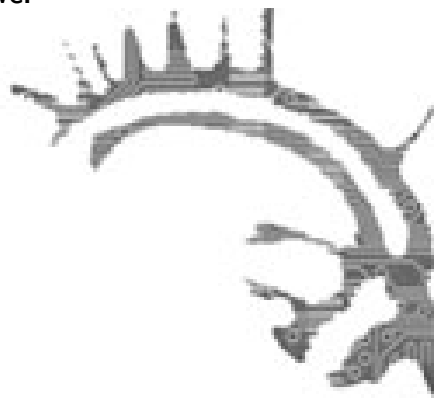

Käyttötarkoitussidonnaisuus ja vanhat haastatteluaineistot

Tiina Mahlamäki

Haastateltava: No, onko se luppaa tässä [tästäkin asiasta] pubbun tässä nauballa.

Haastattelija: On tietenkin.

Haastateltava: Eikë sitä kaiveta kettään ylös jälkeen.

Haastattelija: Ei, tämä menee arkistoon, ei kukaan kaiva.

Haastateltava: No nïn, sitten minä kyllä [..]

Yllä oleva lainaus Turun yliopiston Kulttuurien tutkimuksen laitoksen uskontotieteen ja folkloristiikan äänitearkiston haastattelunauhasta on monin tavoin kiinnostava. Kaikessa lyhykäisyydessään se nostaa esiin ne keskeiset ongelmat, joita kohtaan työssäni laadullisten aineistojen arkistosta vastaavana henkilönä, arkistoaineistoja käyttävänä kulttuurien tutkijana sekä opiskelijoita kenttätyöhön ja arkistoaineistojen käyttöön ohjaavana opettajana. Erikoisen mielenkiintoiseksi sitaatti tulee, kun sitä peilaa voimassaolevaan henkilötietolainsäädäntöön, joka säätelee myös tutkijoiden toimintaa silloin, kun käsitellään henkilötietoja, toisin sanoen, kun tarkastelun kohteena ovat tunnistettavissa olevat tai nimeltä mainitut henkilöt.

Sitaatti kuvaa 1960-luvun lopun haastattelutilannetta, jossa haastateltava empii käsitellä arkaluontoiseksi kokemiaan seikkoja. Haastattelija rauhoittelee tätä huomauttamalla, että haastattelu sijoitetaan arkistoon, jossa sitä ei kukaan "kaivele". Sitaatti tuo esiin suuren yleisön näkemyksen arkistosta pölyttyvinä mappeina, hapertuvina ja kellastuvina asiakirjoina ja toinen toisensa päälle kertyvinä haastattelunauhoina - joita kukaan ei käytä ja jotka jäävät vuosikymmeniksi arkiston rauhaan koskemattomiksi kartuttaen kulttuuriperinnön mittavaa mutta vaikeasti hahmotettavaa kokonaisuutta. Näin tietysti osalle arkistoidusta aineistosta tapahtuukin.

Tutkijan näkökulma arkistoon on toisenlainen: arkistot ovat nimenomaan "kaivelun" paikkoja. Ne ovat pitkäveteisen paperien lukemisen, loputtomien haastattelunauhojen kuuntelun sekä päiväkausia jatkuvan arkistokorttien selailun paikkoja. Ne ovat myös palkitsevia löytämisen paikkoja, kun esiin nousee ennennä- 
kemättömiä tiedonmurusia tai viitteitä toisiinsa kytkeytyvistä aineistoista, polkuja kohti uusia tietoja ja aineistoja. Tutkija asettaa arkiston kätköistä löytämälleen aineistolle kysymyksiä, joihin saadut vastaukset sitten tutkimuksissa raportoidaan suurelle yleisölle tai ainakin omalle tutkimusyhteisölle.

\section{ARKISTOT JA HENKILÖTIETOLAKI}

Haastattelija antaa siis edellä ristiriitaisen lupauksen: hän lupaa, että aineistot arkistoidaan, mutta samalla hän vakuuttaa, ettei niitä kukaan kaivele. Tämän päivän tutkijat ovat luonnollisesti, tai ainakin toivottavasti, selvillä niistä lainsäädännöllisistä seikoista, jotka toisaalta rajoittavat aineistonkeruuta ja sen tutkimuskäyttöä sekä toisaalta ohjaavat informoimaan tutkittavaa haastattelun tarkoituksesta ja aineiston tulevasta sijoittamisesta ja mahdollisesta jatkokäytöstä. Nämä asiat määritellään joulukuussa 1999 voimaan tulleessa henkilötietolaissa (HetiL 523/99), jota sovelletaan, kun käsitellään "kaikenlaisia luonnollista henkilöä tai hänen ominaisuuksiaan tai elinolosuhteitaan kuvaavia merkintöjä’. Näistähän kulttuurien tutkija juuri on kiinnostunut. Haastateltaville on informointivelvollisuuden nojalla kerrottava, mihin kerättyä aineistoa tullaan käyttämään. Tämä sisältää paitsi kyseessä olevan tutkimuksen myös mahdollisen arkistoinnin ja jatkokäytön. (1) (Kuula 2001a, 4-5; 2001b, 10.)

Henkilötietolaki on käyttötarkoitussidonnaisuuden osalta erityisen tiukka: henkilötietoja sisältävää tutkimusaineistoa saa käyttää vain siihen nimenomaiseen tarkoitukseen, johon suostumus on saatu. Tämä herättää tietysti suuria kysymyksiä kohdistuen vanhoihin aineistoihin, joita kerättäessä ei haastateltavia juurikaan informoitu tai kerrottiin vain yleisesti aineistojen mahdollisesta arkistoinnista. Vanhoja aineistoja ei kuitenkaan tämän vuoksi tarvitse hävittää tai jättää käyttämättä. Lakiin viranomaisten toiminnan julkisuudesta (JulkL 621/99) on sisällytetty poikkeus (37 \$), joka mahdollistaa ennen lain voimaantuloa kerätyn aineiston käyttämisen tieteellisessä tutkimuksessa. Käyttötarkoitus ei kuitenkaan saa olennaisesti poiketa siitä tarkoituksesta, jota varten tiedot on alunperin annettu. (Kuula 2001a, 5.) Lainsäädäntöä ei siis pidä nähdä pelkästään rajoituksena vaan mahdollisuutena. Se tukee tutkimusta sekä mahdollistaa ja ohjaa tutkimusaineistojen arkistointia ja uudelleenkäyttöä. Perustarkoituksena esimerkiksi henkilötietolaissa on - ainakin kulttuurien tutkijan näkökulmasta - informanttien suojelu.

Kulttuurien tutkija voi siis huokaista helpotuksesta. Vanhojenkaan aineistojen käyttö ei ole vielä lainvastaista. Entä esimerkkitapauksemme? Haastateltavalle on luvattu, että aineisto arkistoidaan - mutta myös ettei sitä kaivella. Estääkö se aineistojen käytön uusissa tutkimuksissa? Tähän kysymykseen voidaan vastata kahdella tavalla. Ensinnäkin aineisto voidaan anonymisoida, kuten edellä olevassa sitaatissa olen tehnyt. En kerro, kuka haastattelee tai ketä haastatellaan, milloin tai missä. Ajoitan haastattelun vain 1960-luvun lopulle. Tämän artikkelin tarkoituksiin anonymisointi sopii hyvin. Ei aineiston kontekstista tarvitse tämän enempää tässä yhteydessä tietääkään. Mutta useimmiten muistitietoa käytetään tutkimuksissa, joissa 


\section{MITÄ TULIKAAN LUVATTUA?}

käsitellään tiettyjä ihmisiä, tiettynä aikana ja tietyssä paikassa. Anonymisoinnin yhteydessä menetetään siis osa tutkimuksellisesti merkityksellistä informaatiota, mutta aineisto voidaan arkistoida ja sitä voidaan vapaasti käyttää uusissa tutkimuksissa.

Toinen tapa - joka ymmärtääkseni useimmiten käytössä perinnetieteellisissä tutkimuksissa - on luottaa siihen, että haastattelijan ja haastateltavan välillä on tehty niin sanottu hiljainen sopimus. Haastateltavan oletetaan olevan tietoinen siitä, että haastattelu tehdään nimenomaan tieteellistä tutkimusta varten ja se arkistoidaan. Tämä mahdollistaisi paitsi aineiston arkistoinnin myös sen käytön uusissa tutkimuksissa. Lisäksi sille voisi asettaa uusia kysymyksiä. Sen sijaan sopimus ei vapauttaisi paljastamaan informantin nimeä. Tutkittavan nimen käyttö julkaisuissa edellyttää henkilötietolain mukaan dokumentoitua lupaa. (Kuula 2001a; ks. myös Mahlamäki 2002.)

Alun sitaatti liittyy myös lakiin viranomaisten toiminnan julkisuudesta. (2) Laissa nimittäin määritellään yksityishenkilöitä koskevat arkaluontoiset asiat salassapidettäviksi. Arkaluontoisten asioiden lista (24 §) on laissa pitkä ja sisältää muun muassa yksityishenkilön rikosasioihin, terveydentilaan, sosiaalihuollon palveluihin, seksuaaliseen suuntautumiseen tai käyttäytymiseen ja poliittiseen vakaumukseen liittyvät seikat. Lisäksi laissa määritellään salassapidettäviksi muun muassa asiakirjat, jotka käsittelevät henkilön mielipiteitä, elintapoja, vapaa-ajan harrastuksia ja perhe-elämää. Paljonpa jäisi tutkittavaa, jos arkistoaineistoista nämä kaikki riisuttaisiin pois. Onneksi näin ei ole asianlaita, sillä samassa laissa turvataan myös tieteellisen tutkimuksen vapaus (28 §). Alun sitaatin haastateltava epäröi puhua oikeudenkäyntiin liittyvistä asioista. Haastattelija kehotti häntä jatkamaan, mikä olikin oikein, sillä on tutkijan, ei informantin, velvollisuus huolehtia, ettei saatuja tietoja käytetä väärin, kenenkään vahingoksi tai maineen mustaamiseksi. Tutkijan onkin aina arkaluontoisia seikkoja käsitellessään pohdittava tarkkaan, mitä seurauksia hänen kirjoituksellaan voi mahdollisesti olla. Tämä on luonnollisesti itsestään selvää ja erityisen selvää se on silloin, kun tutkija itse kerää aineistonsa ja luo vuorovaikutussuhteen haastateltaviinsa. Helpommin asia unohtuu, kun käsitellään arkistosta löytyviä, muiden tuottamia aineistoja.

Tekstini aloittava sitaatti ei tullut käteeni tietoisen etsimisen tuloksena vaan sattumalta. Olin esittelemässä ensimmäisen vuoden opiskelijoille arkiston tiloja ja aineistoja ja nappasin ensimmäisen eteeni osuneen mapin, josta näytin, millainen on haastattelunauhasta tehty pöytäkirja ja sanatarkka litteraatio. Tilanne oli miltei koominen, olinhan juuri luennoinut samoille opiskelijoille henkilötietolaista ja siitä, miten tarkkaan haastateltavia tulee informoida ja miten sitovaa informointi on. Pysäyttävä ja ajatuksia herättävä tilanne se joka tapauksessa oli. En tässä halua syyttää tai syyllistää aiempia tutkijasukupolvia huolettomasta suhtautumisesta informantteihinsa tai haastatteluaineistoihin. Jokainen tutkijasukupolvi työskentelee oman aikansa tutkimuksenteon käytäntöjen ja tutkimuseettisten normistojen mukaisesti. Haluan vain herättää ajatuksia ja toivottavasti myös keskustelua aihees-

ta tai ainakin herkistää tutkijoiden mielet huomioimaan arkistoaineistojen tämänkin puolen. 


\section{VIITTEET}

1. Lisäksi informointivelvoitteeseen kuuluu kertoa tutkittavalle tutkimukseen osallistumisen vapaaehtoisuudesta, tutkimuksen toteuttajasta ja vastuuhenkilö(i)stä sekä henkilötietojen suojaustavoista, säilytysajoista ja mahdollisesta anonymisoinnista.

2. Laki viranomaisten toiminnan julkisuudesta koskee viranomaisten tuottamia asiakirjoja, jollaisia tutkimusaineistot eivät tarkkaan ottaen ole. Mutta koska haastatteluaineistot useimmiten käsittelevät yksityisyyteen liittyviä asioita, niitä on käytännössä käsiteltävä, kuten arkaluontoista tietoa koskevia asiakirjoja.

\section{TutKImusaineistot}

Turun yliopisto, kulttuurien tutkimuksen laitoksen arkistot.

Aänitteet:

— TKU/A/68/301. Esitetään tutkimuseettisistä syistä anonyymina esimerkkinä.

\section{KirjallisuUs}

KUULA, ARJA 2001a: Henkilötietolain soveltaminen tieteelliseen tutkimukseen. - Tietoarkisto, joulukuu 2001:4-6 [online]. <http://www.fsd.uta.fi/tietoarkistolehti/ 06/lehti.pdf $>$ [15.3.2005.]

— 2001b: Käytännön ohjeita. - Tietoarkisto, joulukuu 2001: 10-11 [online]. < http:/ /www.fsd.uta.fi/tietoarkistolehti/06/lehti.pdf> [13.3.2005.]

MAHLAMÄKI, TIINA 2002: Löytyykö se netistä? Digitaalisen tutkimusaineiston erityispiirteitä. - Elore 9(2) [online]. <http://cc.joensuu.fi/ loristi/2_02/ mah202.html> [13.3.2005.]

Tiina Mahlamäki (FM) on uskontotieteen assistentti, jonka vastuualueeseen kuuluu Turun yliopiston Kulttuurien tutkimuksen laitoksen arkistojen TKU-kokoelma. 